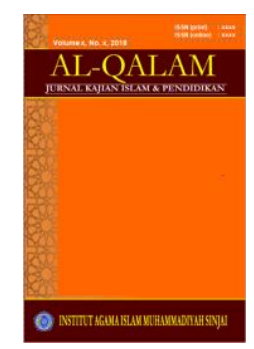

AL-QALAM

Jurnal Kajian Islam \& Pendidikan

Volume 9, No. 1, 2017

ISSN (print) : 1858-4152

ISSN (online) : xxxx-xxxx

Homepage : http://journal.iaimsinjai.ac.id/index.php/al-qalam

\title{
PENDIDIKAN ISLAM DAN PERANANNYA DALAM \\ MENGAKTUALISASIKAN FITRAH MANUSIA \\ (Tantangan dan Eksistensinya)
}

\author{
Oleh: Suriyati ${ }^{1}$
}

\begin{abstract}
$* * *$
Abstrak

Sebagaimana diketahui bahwa fitrah yang dibawa sejak lahir, merupakan potensi yang perlu ditumbuh kembangkan lewat pendidikan dalam hidup dan kehidupan manusia. Pendidikan sangat urgen peranannya dalam mengungkapkan, mengembangkan serta mengaktualisasikan fitrah atau potensi manusia dilingkungan dimana manusia itu berada. Di dalam kehidupan, manusia diperhadapkan berbagai macam tantangan, cobaan yang kesemuanya ini memerlukan suatu kesiapan yang dini dalam menghadapinya. Apabila didalam pertumbuhan dan perkembangan fitrah itu, dimana lingkungan manusia itu berada tidak sesuai dengan tuntutan fitrah yang dibawahnya, maka ia akan mengalami krisis moral dalam kehidupannya, sehingga tuntutan dan harapan akan menjadi manusia yang mengabdikan diri kepada Allah, bangsa dan Negara tidak akan tercapai. Disinilah letak peranan pendidikan Islam, karena pendidikan merupakan satu jembatan emas dalam menyapaikan ajaran-ajaran Allah lewat pesuruhnya Muhammad saw yang tersurat dalam al-Qur'an dan sunnah Rasul, pendidika Islam merupakan peletak dasar dalam pertumbuhan dan perkembangan manusia.
\end{abstract}

Kata Kunci: Pendidikan Islam, Fitrah, Manusia

\section{PENDAHULUAN}

$\mathrm{H}$

akekat manusia adalah makhluk yang paling mulia di sisi Allah SWT, namun pertumbuhan dan perkembangannya itu dapat dibentuk dari berbagai aspek, yaitu aspek jasmani dan rohani. Dari pertumbuhan jasmaniah yang baik akan menumbuhkan dan membentuk tumbuh manusia yang sempurna menurut pandangan dan ukuran jasmaniah, sedangkan segi rohaniah

\footnotetext{
${ }^{1}$ Dosen Tetap Institut Agama Islam Muhammadiyah Sinjai
} 


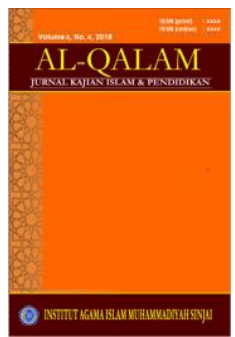

AL-QALAM

Jurnal Kajian Islam \& Pendidikan

Volume 9, No. 1, 2017

ISSN (print) : 1858-4152

ISSN (online) : $\mathrm{xxxx}-\mathrm{xxxx}$

Homepage : http://journal.iaimsinjai.ac.id/index.php/al-qalam

akan memandang manusia tidak lebih mendalam yaitu mental, jiwa, sikap hidup dan nilai pada manusia itu sendiri

Oleh karena itu, manusia dikatakan manusia bila semua unsur pada diri itu terjadi dengan baik dalam suatu kebutuhan yang tak dapat dipisahkan, kesempurnaan manusia itulah dikatakan fitrah, dan fitrah manusia dapat terwujud dengan baik hanya melalui pendidikan pada umumnya dan pendidikan Islam pada khususnya.

Imanuel Kant berpendapat yang disinyalir oleh Suwarno bahwa "Manusia hanya dapat menjadi manusia karena pendidikan"2 Dengan demikian pendidikan merupakan sumber pengetahuan diri disamping juga merupakan bimbingan jasmani dan rohani. Ahmad D. Marimba mengatakan bahwa pendidikan adalah bimbingan jasmani dan rohani berdasarkan hokum-hukum Islam menuju kepada terbentuknya kepribadian utama menurut ukuran-ukuran Islam. ${ }^{3}$

Dari kedua pendapat tersebut di atas dapat dipahami bahwa pendidikan merupakan factor yang sangat dibutuhkan oleh manusia untuk dapat mewujudkan fitrahnya. Fitrah atau potensi yang ada pada anak tentu tidak begitu saja dapat direalisasikan atau diwujudkan, akan tetapi potensi-potensi tersebut hatus tumbuh kembangkan lewat latihan-latihan. Disamping itu tiap-tiap potensi atau kesanggupan mempunyai masa kematangan masing-masing, kesanggupankesanggupan untuk dapat berjalan atau bercakap yang telah ada dalam pembawaannya akan berkembang disebabkan oleh factor lingkungan dan kematangannya.

Kemampuan-kemampuan yang dimiliki manusia ini, dapat membutuhkan faktor-faktor yang dapat merespon dalam pertumbuhan dan perkemabagannya, sehingga hal ini M.J. Langevald mengutarakan pandangannya tentang eksistensi manusia dalam tiga hakekat:

${ }^{2}$ Suwarno, Pengantar Umum Pendidikan, Cet. II; Jakarta: Aksara Baru, 1985), h.40

${ }^{3}$ Ahmad D. Marimba, Pengantar Filsafat Pendidikan Islam, (Cet. IV, Bandung: PT AlMa'arif 1981), h. 25 


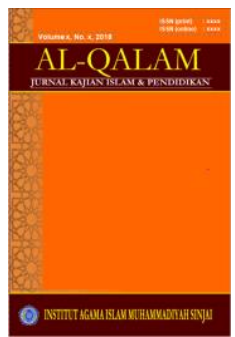

AL-QALAM

Jurnal Kajian Islam \& Pendidikan

Volume 9, No. 1, 2017

ISSN (print) : 1858-4152

ISSN (online) : $\mathrm{xxxx}-\mathrm{xxxx}$

Homepage : http://journal.iaimsinjai.ac.id/index.php/al-qalam

1. Memandang manusia sebagai animal educandum, yaitu manusia merupakan hewan atau makhluk yang harus di didik. Oleh karena itu menjadi manusia yang kita harapkan, adalah manusia yang berbudaya. Hal ini dapat dibuktikan dengan diketemukannya manusia yang hidup dalam rimba bersama-sama dengan binatang-binatang di hutang India, manusia itu tidak bercakap-cakap seperti manusia biasa, ia tidak dapat berjalan tegak diatas kedua kakinya, melainkan merangkak dengan keempat anggotanya. Demikianlah untuk menjadi manusia - manusia berbudaya maka pendidikan itu mutlak adanya, dengan demikian dapat dikatakan bahwa pendidikan itu tidak lain daripada memanusiakan atau menhumanisasikan manusia.

2. Memandang manusia sebagai animal educabile, yaitu manusia adalah makhluk atau hewan yang dapat didik, dengan bertitik tolak kepada keyakinan bahwa manusia itu dapat di didik, maka kita dapat mendidik manusia dengan harapan dan penuh keyakinan akan memberikan hasil dan manfaat baik dirinya, masyarakat, bangsa dan Negara.

3. Memandang manusia sebagai manusia aktif yaitu makhluk yang didalam dirinya terdapat adanya kecendrungan, naluri untuk membentuk dirinya sendiri, inilah yang merupakan sebagian dari potensi modal dalam pembentukan. $^{4}$

Berdasarkan beberapa hakekat yang dikemukakan diatas secara keseluruhan adalah merupakan suatu potensi yang membutuhkan pertumbuhan dan perkembangan. Memandang anak dengan segala sifatnya yang serba tak berdaya, anak dengan serba menggantungkan diri dan membutuhkan pertolongan, bantuan dari orang lain serta didalam dirinya tersimpan dan inisiatif untuk turut serta dalam membentuk dirinya menuju kedewasaan

\section{METODE PENELITIAN}

${ }^{4}$ Lihat pandangan M.J. Langaveld dalam buku Amir Daien Indrakusuma, Pengantar Ilmu Pendidikan, (Cet. I; Surabaya: Usaha Nasional, 1973), h. 50 


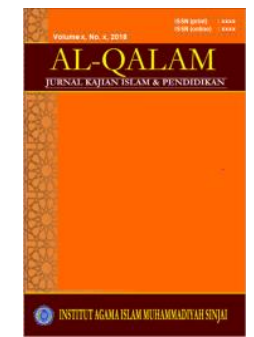

Volume 9, No. 1, 2017

ISSN (print) : 1858-4152

ISSN (online) : :xxx-xxxx

Homepage : http://journal.iaimsinjai.ac.id/index.php/al-qalam

Penelitian ini berbentuk penelitian kepustakaan (Library Research). Dalam penenlitian ini, peneliti menggunakan metode analisis deskriptif, analisis deskriptif adalah suatu metode dengan mengumpulkan data, mesnyusun atau mengklasifikasi, menganalisis dan menginterpretasikannya. Dengan tahapan-tapan sebagai berikut:

1. Mengumpulkan sumber referensi yang berkaitan dengan masalah yang diteliti serta memperlajarainya.

2. Setelah sumber referensi terkumpul diklasifikasikan data yang terdapat pada obyek penelitian dengan landasan teori yang telah diperoleh dari sumber-sumber referensi.

3. Membaca untuk memperoleh data yang dibutuhkan kemudian diklasifikasikan sesuai denganm sifat yang diperoleh.

4. Kemudian dilakukan proses analisa mengenai topik permasalahan yang diteliti.

\section{PEMBAHASAN}

\section{A. Peran Pendidikan Islam}

\section{Pengertian Pendidikan Islam}

Para ahli memberikan pengertian tentan pendidikan agama Islam terdapat bermacam-macam pendapat, baik dari segi sistem, isi maupun dalam bentuk pendidikan agama, hal ini dikarenakan adanya sudut pandang mereka tentang pendidikan agama itu sendiri. Dalam hal ini akan dipaparkan beberapa pendapat antara lain: Para ahli memberikan pengertian tentang pendidikan agama Islam terdapat bermacam-macam pendapat, baik dari segi system, isi maupun dalam bentuk pendidikan agama, hal ini dikarenakan adanya sudut pandang mereka tentang pendidikan agama itu sendiri. Dalam hal ini akan dipaparkan beberapa pendapat antara lain:

Ahmad D, Marimba berpendapat bahwa "Pendidikan Islam adalah bimbingan jasmani dan rohani berdasarkan hokum-hukum agama Islam menuju 


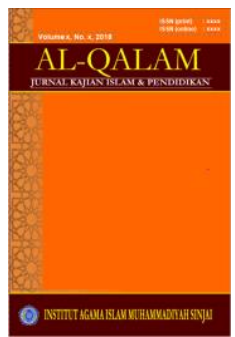

kepada terbentuknya kepribadian utama menurut ukuran-ukuran Islam. ${ }^{5}$ Pada hakekatnya pendidikan secara umum adalah suatu proses pendewasaan manusia. Islam menganggapnya sebagai proses pembinaan kesempurnaan akhlak manusia yang berlansung seumur hidup, agar ia mau dan mampu mengembangkan akal untuk menunaikan amanat Allah sebagai khalifah menata budaya ummat manusia di muka bumi ini. Bertolak dari uraian diatas, maka Shofyan Ahmad mengemukakan defenisi pendidikan Islam adalah:

"Pendidikan Islam adalah pemindahan dan pewarisan isi kebudayaan Islam untuk menyempurnakan segala kecakapan anak didik dalam menghadapi tantangan jaman dan cita-cita Islam.."

Dari beberapa defenisi yang dikemukakan di atas tidak ada satupun yang menganggap bahwa pendidikan agama Islam itu tidak merupaka satu usaha atau aktifitas manusia (yang beragama Islam), namun ada pengertian-pengertian lain dimana orang cendrung untuk mempersamakan pendidikan agama dengan pengajaran agama, sebenarnya pada dasarnya berbeda, kalau dikatakan pendidikan agama berarti menyangkut teori atau konsep atau metode. Oleh karenanya pendidikan agama bersifat teritis. Sedangkan pengajaran agama adalah materi pendidikan agama Islam yang diajarkan kepada peserta didik di sekolahsekolah atau di lembaga-lembaga lainnya yang sifatnya praktis.

Dalam hal ini Burlian memberikan uraian tentang pengajaran sebagai berikut: Pengajaran itu memberikan pengetahuan, pemberian ilmu sehingga orang yang diajar itu menjadi berpengertahuan dan berilmu. Pengajar berusaha untuk memindahkan pengetahuan atau ilmu yang dimilikinya kepada peseta didik. Mengenai pendidikan dan pengajaran lebih jauh dikatakan, bahwa pendidikan jauh lebih luas dan tinggi tarafnya dari pengajaran bahkan pengajaran itu termasuk kedalam pendidikan dengan lain perkataan pendidikan otomatis mengandung pengajaran, tetap pangajaran tidak mangandung pendidikan. Pendidikan tidak

5 Ahmad D. Marimba, Pengantar Filsafat Pendidikan Islam, (Cet. IV, Bandung: AlMa'arif, 1981), h. 23

${ }^{6}$ Sofyan Ahmad, Pembinaan dan Pengembangan Sistem Pendidikan Islam, (Cet. I, Bandung: PT. Al-Ma'arif, 1982), h. 10 


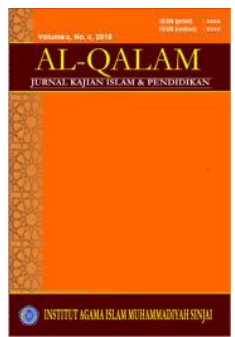

Volume 9, No. 1, 2017

ISSN (print) : 1858-4152

ISSN (online) : xxxx-xxxx

Homepage : http://journal.iaimsinjai.ac.id/index.php/al-qalam

hanya menganggap akal saja, melainkan menggarap seluruh bagian-bagian jiwa (rasa, akal, kehendak, ingatan). ${ }^{7}$

Agama mempunyai peranan yang sangat penting dalam hidup dan kehidupan manusia, karena tidak hanya mengatur kehidupan diakhirat saja, tetapi juga mengatur bagaimana seharusnya manusia hidup di dunia ini. Agama mengajarkan nilai - nilai moral dan mengajak manusia berbuat dalam hubungannya dengan alam dan sesama manusia. Pikiran manusia selalu cendrung untuk subyektif, yaitu selalu memandang sesuatu itu sebagai benar apabila akan menguntungkan bagi dirinya.

Sedangkan kebenaran yang hakiki adalah yang datang dari Tuhan. Allah berfirman dalam al-Qur'an surah al-Baqarah ayat 147

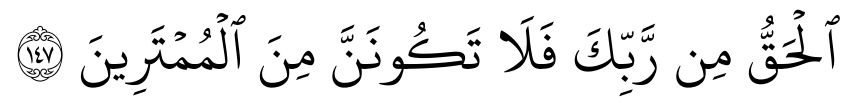

Terjemahnya:

Kebenaran itu adalah dari Tuhanmu, sebab itu jangan sekali-kali kamu Termasuk orang-orang yang ragu. ${ }^{8}$

Dari ayat diatas dapat dipahami bahwa hakikatnya suatu kebenaran hanyalah kebenaran dari Allah. Dengan demikian dalam usaha menjadikan ajaran agama sebagai referensi dari setiap gerak langkah seseorang, maka pelajaran agama harus diberikan sedini mungkin, mulai dari bersifat pembiasaan dirumah tangga sampai kepada pendidikan formal di lembaga-lembaga pendidikan.

Pendidikan agama di sekolah dapat dianggap sebagai lanjutan dari usaha membina secara formal pendidikan agama yang telah dimulai di rumah tangga, yaitu memupuk jiwa keagamaan yang telah dimiliki.

1. Mendorong terbentuknya kebiasaan dan tumbuhnya iman serta sikap hidup sesuai dengan ajaran Islam

${ }^{7}$ Lihat Burlian Somat, Beberapa Persoalan dalam Pendidikan Islam, (Cet. I, Bandung: Al-Ma-arif, 1981).h.17-18

${ }^{8}$ Departemen Agama RI, Al-Qur'an dan Terjemahnya, (Jakarta : Yayasan Penyelenggara Penterjemah Al-Qur'an, 1979), h.37 


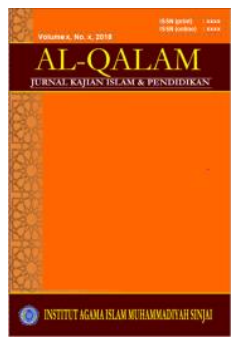

AL-QALAM

Jurnal Kajian Islam \& Pendidikan

Volume 9, No. 1, 2017

ISSN (print) : 1858-4152

ISSN (online) : xxxx-xxxx

Homepage : http://journal.iaimsinjai.ac.id/index.php/al-qalam

2. Menunjang tercapainya tujuan pendidikan Nasional

Ini berarti bahwa materi yang diajarkan di sekolah tidak boleh bertentangan dengan pengetahuan yang telah diterima peserta didik dari rumah, dan harus menimbulkan motivasi agar peserta didik mau melaksanakan ajaran itu hingga terbentuk manusia pembangunan yang bertaqwa terhadap Allah swt.

\section{Dasar dan Tujuan Pendidikan Islam}

Mendahului uraian tentang dasar dan tujuan pendidikan Islam. Tujuan dan dasar pendidikan umum. Di dalam Undang-Undang No. 20 tahun 2013 bab 2 yang berbunyi: Pendidikan Nasional berdasarkan pancasila dan Undang-Undang Republik Indonesia (pasal 1)

Pendidikan adalah usaha sadar dan terencana untuk mewujudkan suasana belajar dan proses pembelajaran agar peserta didik secara aktif mengembangkan potensi dirinya untuk memiliki kekuatan spiritual keagamaan, pengendalian diri, kepribadian, kecerdasan, akhlak mulia, serta keterampilan yang diperlukan drinya, masyarakat, bangsa dan Negara. ${ }^{9}$

Dari tujuan pendidikan nasional di atas dapat dipahami bahwa, kata iman merupakan suatu cirri pembangunan kualitas manusia Indonesia yang professional dalam berbagai bidang kehidupan. Kemajuan-kemajuan tersebut mengacu kepada suatu tatanan nilai yang kokoh dalam derap langkah pembentukan kualitas manusia, dengan demikian akan lahir manusia-manusia yang mempunyai kualitas iman yang tinggi, pendirian yang tangguh, mandiri serta dapat bertanggung jawab atas dirinya, masyarakat bangsa dan Negara.

Dalam pelaksanaan pendidikan islam secara operasional di Indonesia, maka dasar-dasar pelaksanaanya cukup kuat. Zuharaini meninjau dari beberapa segi atau dasar:

1. Dasar dari segi yuridis / hokum yakni dasar dari peraturan perundangundangan dijadikan pegangan dalam pelaksanaan pendidikan agama Islam di

${ }^{9}$ Undang-Undang RI, No 20 Tahun 2013, Tentang Sistem Pendidikan Nasional, (Jakarta : PT. Armas Duta Jawa, 1989), h. 73 


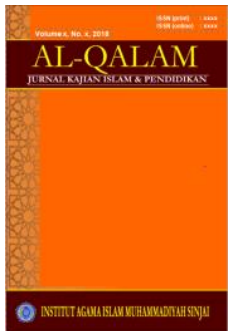

Volume 9, No. 1, 2017

ISSN (print) : 1858-4152

ISSN (online) : :xxx-xxxx

Homepage : http://journal.iaimsinjai.ac.id/index.php/al-qalam

sekolah-sekolahdi Indonesia. Adapun dasar dari segi yuridis formil tersebut ada tiga macam antara lain:

2. Dasar religious, yang dimaksud dengan dasar ni adalah dasar-dasar yang bersumber dari ajaran Islam (al-Qur'an al-Hadis) menurut pandangan Islam tentang pendidikan adalah merupakan perintah dari Allah swt, dan merupakan ibadah kepada-Na

3. Dasar dari segi social psikologi, dalam kehidupan manusia selalu membutuhkan satu pandangan hidup yang disebut dengan agama. Mereka merasakan bahwa di dalam jiwanya ada suatu perasaan yang mengakui ada zat yang maha kuasa, tempat berlindung dan bermohon pertolongan-Nya. ${ }^{10}$

Dari beberapa dasar diatas, apabila dihubungkan dalam Islam terdapat beberapa dalil antara lain dalam surah At-taubah ayat 122 yaitu:

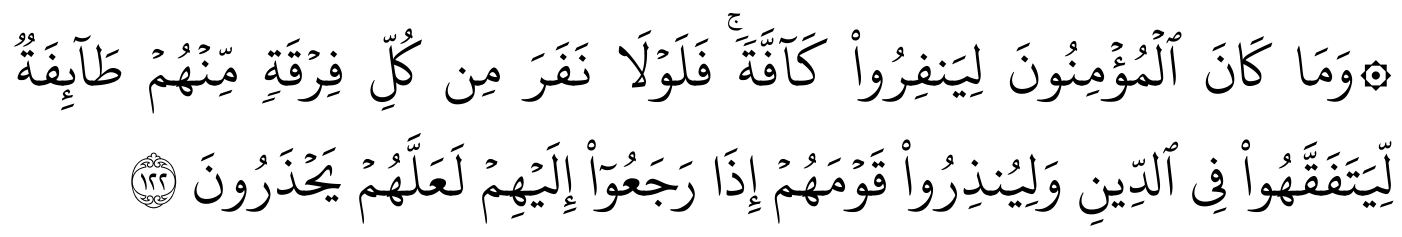

Terjemahnya:

Tidak sepatutnya bagi mukminin itu pergi semuanya (ke medan perang). mengapa tidak pergi dari tiap-tiap golongan di antara mereka beberapa orang untuk memperdalam pengetahuan mereka tentang agama dan untuk memberi peringatan kepada kaumnya apabila mereka telah kembali kepadanya, supaya mereka itu dapat menjaga dirinya. ${ }^{11}$

Di dalam surah An-Nahl : 125 Allah berfirman :

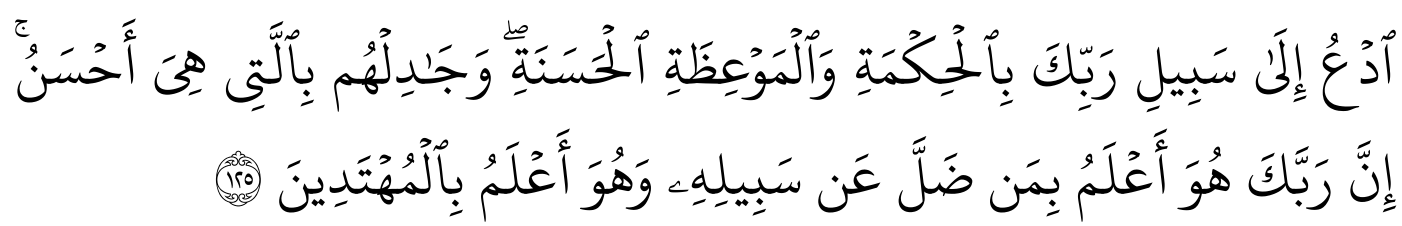

Terjemahnya:

Serulah (manusia) kepada jalan Tuhan-mu dengan hikmah dan pelajaran yang baik dan bantahlah mereka dengan cara yang baik.

${ }^{10}$ H. Zuhairini, Abd. Gofir, Slamet AS, Yunus, Op. cit, h. 19-23

11 Departemen Agama RI, Al-Qur'an dan Terjemahnya, (Jakarta : Yayasan Penyelenggara Penterjemah Al-Qur'an, 1979), h. 301 


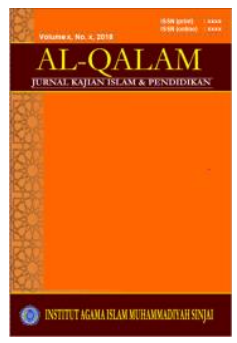

AL-QALAM

Jurnal Kajian Islam \& Pendidikan

Volume 9, No. 1, 2017

ISSN (print) : 1858-4152

ISSN (online) : :xxx-xxxx

Homepage : http://journal.iaimsinjai.ac.id/index.php/al-qalam

Maksud dari ayat diatas bahwa hikmah: ialah Perkataan yang tegas dan benar yang dapat membedakan antara yang hak dengan yang bathil. Dari dalil diatas dapat dipahami bahwa di dalam pandangan Islam ada kewajiban terhadap masalah pendidikan, baik itu pendidikan sekolah maupun pendidikan diluar sekolah. Pendidikan nasional bertujuan untuk meningkatkan kualitas manusia Indonesia yaitu manusia Indonesia yang beriman dan bertaqwa terhadap Tuhan Yang Maha Esa, berbudi pekerti luhur, berkepribadian, berdisiplin, bekerja keras, tangguh, bertanggung jawab, mandiri, cerdas dan teranpil serta sehat jasmani dan rohani $^{12}$ Untuk memperjelas tujuan pendidikan Islam, akan diuraikan beberapa pendapat para ahli :

Menurut Muhammad Athia Al- Abrasyi bahwa :

" Tujuan pendidikan Islam yaitu membentuk akhlak dan budi pekerti yang sanggup menghasilkan orang yang normal, kemauan yang keras, cita-cita yang benar dan akhlak yang tinggi, mengetahui arti dan kewajiban pelaksanaanya, menghormati hak-hak manusia, dapat membedakan yang buruk, menghindari suatu perbuatan yang tercela, karena ia tercela, dan mengingat Tuhan dalam setiap pekerjaan yang mereka lakukan. ${ }^{13}$

Zuhairini dkk mengemukakan bahwa tujuan pendidikan umum pendidikan agama ialah membimbing anak agar mereka menjadi orang muslim sejati, beriman teguh, beramal salehdan berakhlak mulia serta berguna bagi masyarakat agama dan Negara. ${ }^{14}$ Sedangkan Muhammad Yunus mengemukakan bahwa: tujuan pendidikan yaitu keagamaan, semata-mata mengajar, belajar karena Allah dan Mengharap keridhaanya. ${ }^{15}$

Dari beberapa tujuan pendidikan yang dikemukakan diatas, baik tujuan pendidikan nasional maupun tujuan pendidikan agama terdapat perbedaan namun

\footnotetext{
${ }^{12}$ Ketetapan MPR RI No. 2/MPR/1988. TAP MPR dan GBHN Tahun 1988, (PT. Beringin Jaya Semarang : 1989), h.77

${ }^{13}$ Muhammad Athia Al-Abrasyi , At-Tarbiyatul Islamiyah, ahli bahasa H. Bustami, dengan Judul "Pendidikan Islam", (Cet. IV, Jakarta : Bulan Bintang, 1977), h. 103

${ }^{14}$ H. Zuhairini, Op.cit, h. 39

${ }^{15}$ Muhammad Yunus, Pokok-Pokok Pendiidkan dan Pengajaran, (Cet. III, Jakarta: Hida Karya Agung, 1978), h. 10
} 


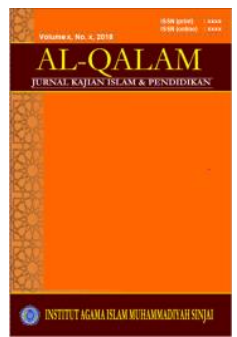

AL-QALAM

Jurnal Kajian Islam \& Pendidikan

Volume 9, No. 1, 2017

ISSN (print) : 1858-4152

ISSN (online) : :xxx-xxxx

Homepage : http://journal.iaimsinjai.ac.id/index.php/al-qalam

dapat disimpulkan bahwa pada tujuannya saling berhubungan antara satu dengan yang lainnya. Dan tujuan akhlak pendidikan Islam sesuai dengan tujuan Allah swt.

Tujuan pendidikan secara praktis adalah bagaimana membentuk manusia agar dapat mengabdi kepada Allah swt. Pengabdian seseorang kepada Allah dapat dilihat dalam sikap perbuatannya, dalam melaksanakan ajaran agama.

\section{Faktor- Faktor Yang Mempengaruhi Pendidikan Islam}

Sebagaimana diketahui bahwa potensi yang dimiliki oleh manusia atau peserta didik perlu ditumbuh kembangkan. Secara umum dapat diketahui bahwa perkemabngan manusia itu tergantung kepada pembawaan atau lingkungan? Untuk terjawab pertanyaan ini dapat dikemukakan beberapa pendapat antara lain:

a. Aliran Nativisme

Aliran ini berpendapat bahwa segala perkembangan manusia itu telah ditentukan oleh factor-faktor yang dibawa sejak lahir. Pembawaan yang terdapat pada waktu dilahirkan itulah yang menentukan hasil perkembangan menurut pembawaan. Lingkungan tidak berpengaruh sama sekali tidaknya perkembangan individu tergantung tinggi rendahnya pembawaan yang dimilki oleh masing-masing peserta didik. ${ }^{16}$

b. Aliran Empirisme

Teori ini berpendapat bahwa hasil pendidikan dan perkembangan tergantung pada pengalaman-pengalaman yang diperoleh peserta didik selama hidupnya. Pengalaman itu diperoleh diluar dirinya berdasarkan peransang yang tersedia baginya, peransang itu dapat tersedia dengan sendirinya atau disediakan oleh apapun dan siapapun juga. Kata empirisme berasal dari kata empiri yang berarti pengalaman, tokoh aliran ini adalah John Locke (1632-1704), seorang h. 15

${ }^{16}$ M. Ngalim Purwanto, Psikologi Pendidikan, (Cet. II, Bandung: Remaja Karya, 1985), 


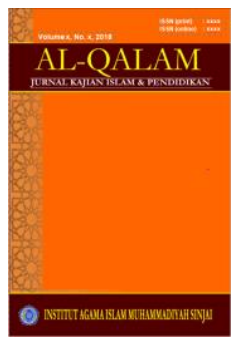

AL-QALAM

Jurnal Kajian Islam \& Pendidikan

Volume 9, No. 1, 2017

ISSN (print) : 1858-4152

ISSN (online) : $\mathrm{xxxx}-\mathrm{xxxx}$

Homepage : http://journal.iaimsinjai.ac.id/index.php/al-qalam

filosof bangsa Inggris, yang berpendapat bahwa anak lahir kedunia ini sebagai kertas kosong atau sebagai meja berlapis lilin yang belum ada tulisan di atasnya, jadi John Locke berpendapat bahwa peserta didik 100\% tergantung pada dunia luar, pendidikan adalah maha kuasa dalam membentuk peserta didik menjadi apa yang diinginkannya.

c. Aliran Konvergensi

Teori ini berasal dari seorang ahli psikolog bangsa Jerman bernama Wilian Stern. Ia berpendapat bahwa pembawaan dan lingkungan kedua-duanya menentukan perkembangan manusia. Menurut aliran ini Nativisme dan Empirisme, kedua-duanya terlalu ekstrim. Kata Covergensi pembawaan maupun lingkungan kedua-duanya mempunyai pengaruh terhadap perkembangan peserta didik, hasil perkembangan dan pendidikan tergantung kepada kecilnya pembawaan secara situasi lingkungannya. ${ }^{17}$

Dengan demikian dapat diketahui bahwa baik pembawaan maupun lingkungan sangat menentukan proses perkembangan seseorang atau peserta didik. Dalam proses pelaksanaan pendidikan Islam ditentukan oleh beberapa factor antara lain :

1. Faktor peserta didik

Peserta didik adalah merupakan pihak yang dibantu atau pihak yang dibentuk. Sebagai pihak yang dibentuk dalam diri anak terdapat potensi-potensi yang membutuhkan bamtuan yang datang dari luar, yaitu pendidikan. Dalam hal ini akan diketahui bahwa masing-masing anak memiliki potensi sendirisendiriantara anak yang satu dengan anak yang lainnya.

2. Faktor pendidik

Pendidik merupakan pihak yang memberikan bantuan, seperti peserta didik, maka masing-masing pendidik dalam meberikan bantuannya terdapat perbedaan-perbedaan, baik dalam hal cara dan gaya, pendekatana (approach) dalam mendidik anak. Pendidik bertugas sebagai medium agar peserta didik dapat

${ }^{17}$ Ibid, h. 15 


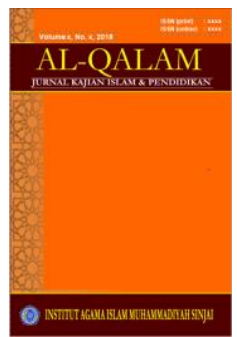

mencapai tujuan pendidikan yang telah dirumuskan, tanpa pendidikan tujuan pendidikan yang telah dirumuskan tidak akan dicapai oleh peserta didik.

3. Faktor lingkungan

Dapat diketahui bahwalingkungan mempunyai peranan yang sangat penting dalam pertumbuhan dan perkembangan peserta didik pengaruh lingkungan dalam pendidikan agama. Penulis dapat uraikan sebagai berikut:

1) Lingkungan keluarga

Sebagaimana diketahui bahwa, seorang anak yang mulai tumbuh dan berkembang pada mulanya diasuh dalam keluarganya yaitu kedua orang tua, karena kedua orang tua mempunyai kewajiban untuk memberikan tuntutan dan bimbingan sesuai dengan ajaran agamanya. Karena anak tersebut lahir dalam keadaan suci serta membawa potensi yang perlu dikembangkan oleh lingkungannya. Disamping pentingnya perhatian orang tua dalam mendidik anak-anaknya, Allah berfirman dalam al-Qur'an surah At-Tahrim ayat 6:

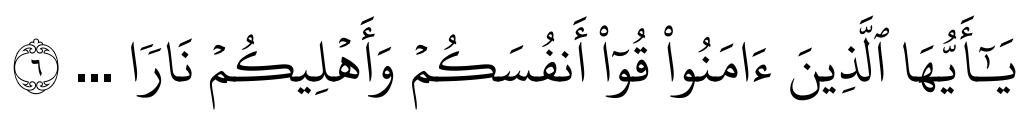

Terjemahnya:

Hai orang-orang yang beriman, peliharalah dirimu dan keluargamu dari api neraka. ${ }^{18}$

Jelaslah, bahwa ayat tersebut diatas menerangkan tentang fungsi dan tanggung jawab orang tua terhadap keluarganya dari siksaan api neraka. Dengan demikian orang tua mempunyai kewajiban untuk memberikan tuntutan yang baik, yang sesuai dengan ajaran agamanya terhadap seluruh keluarga yakni anak dan istrinya sehingga mereka senatiasa berada pada situasi yang harmonis sesuai dengan ajaran agama islam

2) Lingkungan sekolah

Sekolah merupakan lembaga pendidikan yang kedua setelah keluarga yang harus dilalui oleh setiap peserta didik. Mereka diharapkan hendaknya di

${ }^{18}$ Departemen Agama RI, Op.cit, h. 951 


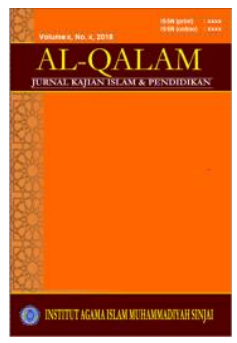

AL-QALAM

Jurnal Kajian Islam \& Pendidikan

Volume 9, No. 1, 2017

ISSN (print) : 1858-4152

ISSN (online) : xxxx-xxxx

Homepage : http://journal.iaimsinjai.ac.id/index.php/al-qalam

dalam sekolah (pendidikan formal) memperoleh kesempatan untuk mengembangkan potensi (bakatnya) yang dibawa sejak lahir. Pendidikan yang berlangsung di sekolah diharapkan dapat mengembangkan cakrawala berfikir sehingga nantinya anak tersebut menjadi matang tentang pengetahuan yang ia peroleh dari bangku sekolah, merupakan landasan berpijak untuk mengarungi kehidupan selanjutnya.

3) Lingkungan masyarakat

Pendidikan dalam masyarakat yang merupakan bentuk pendidikan luar sekolah, biasanya dilalui oleh setiap peserta didik disamping pendidikan dalam sekolah. Dalam masyarakat anak menemukan berbagai macam bentuk kehidupan, pengalaman-pengalaman, permasalahan-permasalahan, yang memerlukan perhatian dan ketelitian dalam menghadapinya.

Dengan demikian, dapat dipahami bahwa peranan lingkungan pendidikan sangat menentukan sikap dan kepribadian anak, baik itu dalam lingkungan sekolah dan ataupun luar sekolah.

4. Faktor metode/alat

Untuk mencapai tujuan pendidikan yang dikehendaki, maka tugas seorang pendidik cukup berat karena kesalahan dalam mengajar bukan hanya membuang waktu dan tenaga tetapi juga merusak jiwa peserta didik yang seharusnya berkembang dengan baik, proses mengajar bukanlah laksana proses memulai suatu reaksi kimia, naumun lebih dari itu karena hati pendidik harus masuk kedalamnya berpautan dengan nilai-nilai luhur kemanusiaan. Metodologi Pendidikan agama adalah ilmu yang membahas rencana tentang penyajian bahan pendidikan agama dan hubngannya dengan factor lain dalam rangka mencapai tujuan pendidikan agama. ${ }^{19}$

5. Faktor tujuan yang hendak dicapai

${ }^{19}$ Mansur, et. Al, Metodologi Pendidikan Agama, (Cet. II, Jakarta: CV. Forum, 1982), h. 13 


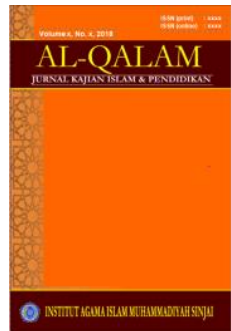

Volume 9, No. 1, 2017

ISSN (print) : 1858-4152

ISSN (online) : :xxx-xxxx

Homepage : http://journal.iaimsinjai.ac.id/index.php/al-qalam

Pendidikan adalah suatu kegiatan yang dilaksanakan untuk mencapai tujuan tertentu. Dalam rangka mencapai tujuan ini maka factor ekonomi tidak bias lepas dengan kegiatan pendidikan

\section{B. Aktualisasi Fitrah Manusia}

\section{Pengertian Fitrah}

Fitrah artinya sifat asal, bakat, pembawaan. ${ }^{20}$ Fitrah berasala dari kata kerja "Fatarah" yang berarti menciptakan. ${ }^{21}$ Jadi Fitrah berarti sifat dasar yang telah ada saat baru diciptakan. Sebagaimana firman Allah di dalam al-Qur'an surah Ar-Rum ayat 30

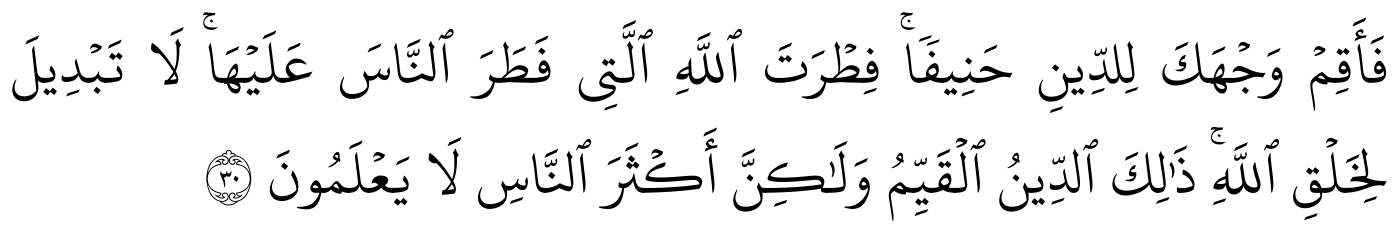

Terjemahnya:

Maka hadapkanlah wajahmu dengan Lurus kepada agama Allah; (tetaplah atas) fitrah Allah yang telah menciptakan manusia menurut fitrah itu. tidak ada peubahan pada fitrah Allah. (Itulah) agama yang lurus; tetapi kebanyakan manusia tidak mengetahui, ${ }^{22}$

Fitrah Allah: Maksudnya ciptaan Allah. manusia diciptakan Allah mempunyai naluri beragama Yaitu agama tauhid. kalau ada manusia tidak beragama tauhid, Maka hal itu tidaklah wajar. mereka tidak beragama tauhid itu hanyalah lantara pengaruh lingkungan.

\section{Konsep Fitrah Manusia}

Konsep fitrah manusia yang mengandung pengertian pola dasar kejadian manusia dapat dijelaskan sebagai berikut:

20 W.J.S. Purwadarminta, Kamus Umum Bahasa Indonesia, (Cet.V, Jakarta: Balai Pustaka, 1976), h. 282

${ }^{21}$ Burlian Somat, Beberapa Persoalan Dalam Pendidikan Islam, ( Cet. I, Bandung: PT. Al-Ma'arif, 1981), h. 34

${ }^{22}$ Departemen Agama RI, 1-Qur'an dan Terjemahnya, (Jakarta: Yayasan Penyelenggara Penterjemah Al-Qur'an, 1979), h. 407 


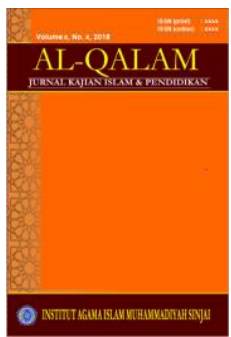

Volume 9, No. 1, 2017

ISSN (print) : 1858-4152

ISSN (online) : :xxx-xxxx

Homepage : http://journal.iaimsinjai.ac.id/index.php/al-qalam
a. Hakekat wujud manusia
b. Tujuan penciptaannya
c. Sumber daya manusia
d. Citra manusia dalam islam

\section{Hubungan Pendidikan Islam dan Keberadaan Fitrah}

Sebagaimana diketahui bahwa, pendidikan pada dasarnya adalah untuk mengembangkan potensi manusia. Allah menciptakan manusia lengkap dengan berbagai potensi kebaikan mempunyai makna dan tujuan tersendiri, potensi yang dimiliki oleh manusia merupakan suatu modal dasar menjalani kehidupannya didunia. Keberadaan manusia di dunia dijelaskan oleh Allah di dalam Al-Qur'an surah Al-Baqarah ayat 30 sebagai berikut:

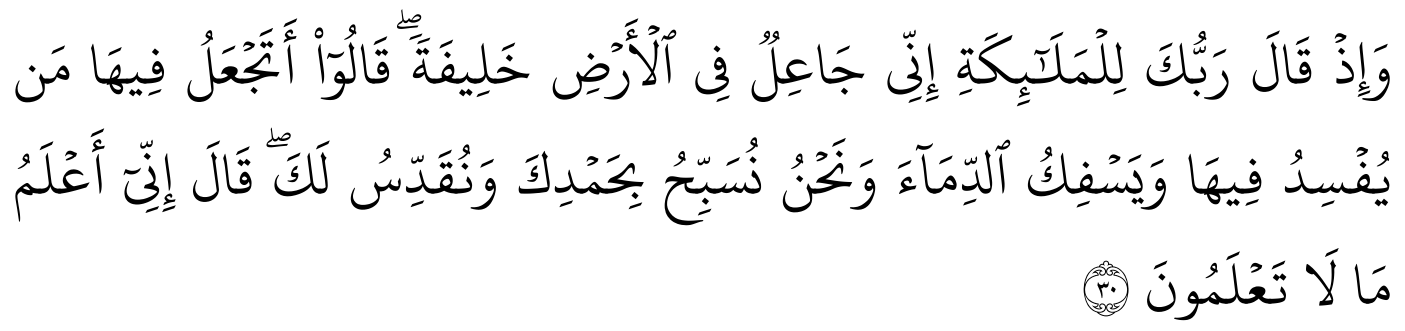

Terjemahnya:

Ingatlah ketika Tuhanmu berfirman kepada Para Malaikat: "Sesungguhnya aku hendak menjadikan seorang khalifah di muka bumi." mereka berkata: "Mengapa Engkau hendak menjadikan (khalifah) di bumi itu orang yang akan membuat kerusakan padanya dan menumpahkan darah, Padahal Kami Senantiasa bertasbih dengan memuji Engkau dan mensucikan Engkau?" Tuhan berfirman: "Sesungguhnya aku mengetahui apa yang tidak kamu ketahui."23

Dari ayat diatas dipahami bahwa kehadiran manusia di dunia adalah utnuk menjadi pemimpin (khalifah), seorang pemimpin (khalifah) adalah pengembang amanah Allah amanat yang perlu dijalankan oleh seorang manusia sesuai dengan aturan dari Allah dan Rasulnya yang termaktud didalam Al-Qur'an dan Al-Hadis.

\section{KESIMPULAN}

${ }^{23}$ Departemen Agama RI, Al-Qur'an dan Terjemahnya, (Jakarta: yayasan Penyelenggara Penterjemah Al-Qur'an 


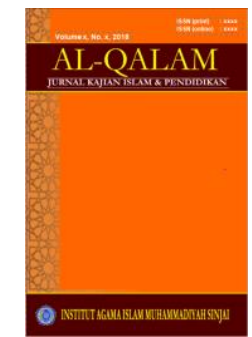

AL-QALAM

Jurnal Kajian Islam \& Pendidikan

Volume 9, No. 1, 2017

ISSN (print) : 1858-4152

ISSN (online) : $\mathrm{xxxx}-\mathrm{xxxx}$

Homepage : http://journal.iaimsinjai.ac.id/index.php/al-qalam

Fitrah atau pembawaan (potensi) merupakan sifat asal yang dibawa sesorang sejak lahir, potensi ini memerlukan pertumbuhan dan perkembangan. Dalam hal pertumbuhan dan perkembangan, factor pendidik sangat menentukan keberhasilan potensi tersebut. Pendidikan Islam sangat berperan dalam pertumbuhan dan perkembangan anak, sebab tanpa upaya dan sentuhan pendidikan agama, fitrah yang dimiliki oleh manusia tidak akan terwujud dengan baik sehingga dalam pembentukan insan qamil yang selalu mendekatkan diri kepada Allah tidak dapat dicapai.

Upaya untuk menumbuh kembangkan fitrah manusia (peserta didik) orang tua sangat menentukan, orang tua sebagai peletak dasar dan sebagai pendidik pertama dan utama, haruslah dapat disadari sepenuhnya, dalam menanamkan nilai-nilai agama pada diri anak, sehingga anak nantinya mencapai tingkat dewasa mampu menghadapi dan menyelesaikan segala tantangan yang dihadapi dalam kehidupannya. Upaya untuk dapat mengaktualisasikan fitrah manusia didalam kehidupannya, agar dapat melaksanakannya amanah Allah dengan baik, sesuai dengan eksistensi kehadirannya dibumi. Maka pendidikan dalam artian yang luas sangat besar peranannya, pendidikan agama salah satu alternative dalam mengantarkan, mengarahkan, serta mengaktualisasikan fitrah manusia ini dalam menghadapi berbagai tantangan dalam perjalanan hidupnya

\section{DAFTAR PUSTAKA}

Ahmad D Marimba, Pengantar Filsafat Pendidikan Islam, Cet. IV, Bandung : PT. Al-Ma'arif 1981

Al-Gazaly yang dikutip oleh H.M. Arifin, M.Ed, Hubungan Timbali Balik Pendidikan Agama di Lingkungan Sekolah dan Keluarga, Cet. II, Jakarta: Bulan Bintang, 1976

Burlian Somat, Beberapa Persoalan Dalam Pendidikan Islam, Cet. I, Bandung: PT. Al-Ma'arif, 1981

Departemen Agama RI, Al-Qu'ran dan Terjemahnya, Jakarta : Yayasan Penyelenggara Penterjemah Al_Qur'an, 1979 


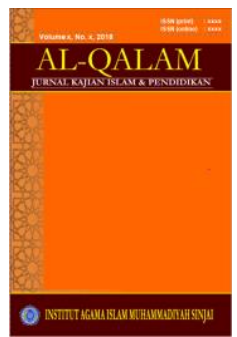

AL-QALAM

Jurnal Kajian Islam \& Pendidikan

Volume 9, No. 1, 2017

ISSN (print) : 1858-4152

ISSN (online) : $\mathrm{xxxx}-\mathrm{xxxx}$

Homepage : http://journal.iaimsinjai.ac.id/index.php/al-qalam

H. Zuhairini, Metode Khusus Pendidikan Agama, Cet. VIII: Surabaya: Usaha Nasional, 1981

, Abd. Gofir, Slamet AS, Yunus, Psikologi Pendidikan, Cet. II, Bandung: Adiatama Surabaya, 1978

Hasan Langgulung, Manusia dan Pendidikan Suatu Analisa Psikologi dan Pendidikan, Cet. I, Jakarta : Al-Husna, 1986

H.M. Arifin, Hubungan Timbal Balik Pendidikan Agama di Lingkungan Sekolah dan Keluarga, Cet. IV, Jakarta : Bulang Bintang, 1978

Ketetapan MPR RI No 2/MPR/1988. TAP MPR dan GBHN Tahun 1988, PT. Beringin Jaya Semarang : 1989

Mansur, Metodologi Pendidikan Islam, Cet. II, Jakarta: CV. Forum, 1982

M. Arifin dan Amiruddin Rasyad, Dasar-Dasar Pendidikan, Ditjen Pembinaan Kelembagaan Agama Islam, Departemen Agama : 1991

Muhammad Yunus, Pokok Pendidikan dan Pengajaran, Cet. III, Jakarta : Hida Karya Agung, 1978.

M. Ngalim Purwanto, Psikologi Pendidikan, Cet. II, Bandung: Remaja Karya, 1985 CV. Remaja Karya, 1989

Sofyan Ahmad, Pembinaan dan Pengembangan Sistem Pendidikan Islam, Cet. I, Bandung : PT. Al-Ma'arif, 1982

W.J.S. Purwadarminta, Kamus Umum Bahasa Indonesia, Cet. V, Jakarta: Balai Pustaka, 1976 